\title{
JUURNAL.RU
}

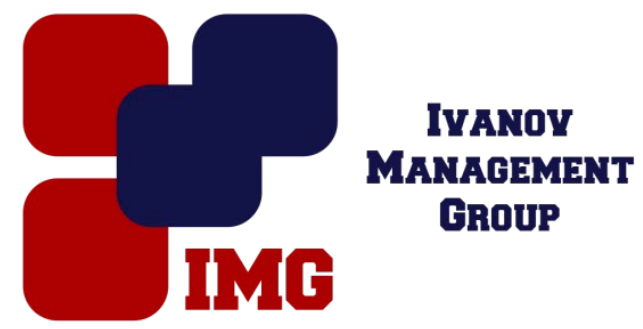

Калашникова С.A. Читинская государственная медииинская академия Чита, Россия

doi: 10.18411/lj-25-12-2016-2-09

idsp 000001:lj-25-12-2016-2-09

\section{Научно-исследовательская работа студентов медицинского вуза в формате ФГОС три плюс в аспекте дисциплин естественнонаучного цикла}

\section{Аннотация.}

В статье показана роль научно-исследовательской работы студентов медицинского вуза в развитии качеств, необходимых при формировании некоторых компетенций ФГОС три плюс.

Ключевые слова: научно-исследовательская работа студентов, дисциплины «Физика, информатика» и «Медицинская информатика», студентымедики.

Согласно ФГОС три плюс после окончания медицинского вуза выпускник должен обладать способностью к участию в проведении научных исследований (ПК-21), а также готовностью к саморазвитию, самореализации, самообразованию, использованию творческого потенциала (ОК-5) [3, с.8, с.12]. Развитию перечисленных выше компетенций может способствовать студенческая научная работа.

В настоящее время практикуется ежегодное проведения студенческих конференций «Медицина завтрашнего дня» в Читинской государственной академии, что является стимулом для раскрытия творческого потенциала студентов и их саморазвитию и самовоспитания. Как правило, студенты работают в малых группах по определённой тематике. За ними закреплён наставник из профессорско-преподавательского состава, который корректирует процесс осуществления исследования, учит правильно оформлять и оценивать результаты измерений. Работа над научным проектом в составе малой группы раскрывает потенциал студентов в области сотрудничества, взаимопомощи и поддержки. В зависимости от тематики работы первоначально происходит наработка теоретического материала с использованием бумажных и интернет ресурсов, определяется новизна, актуальность выдвинутой темы, составляется план исследования. Далее проводится собственно научное исследование, оценка 
полученных результатов. Отчёт о результатах исследования происходит во время научной конференции, где студенты докладывают о полученных результатах, делают выводы относительно своего исследования. Практика представления своей работы на конференции благоприятствует развитию ораторского искусства, умению держаться на сцене, отвечать на неожиданные вопросы. Кроме того, доклады обязательно сопровождаются презентацией, что формирует умения по их созданию и навыки работы с информационными технологиями. Выступление на конференции способствует рефлексии студентов относительно проделанной работы. По результатам конференции издаётся сборник.

На предыдущей конференции студентами лечебного и педиатрического факультетов в секции «Актуальные вопросы симуляционного обучения и учебно-исследовательской работы студентов в медицинском вузе» была представлена тема «Использование симуляционных препаратов, созданных посредством томографических $3 \mathrm{~d}$ реконструкций, в изучении нормальной и патологической анатомии» [1, с.347-348]. Работа в данном направлении позволила углубить знания студентов по теме «Обзор методов анализа медицинских изображений», изучаемой на практических занятиях дисциплины «Медицинская информатика». Стоит заметить, что в настоящее время происходит достаточно широкое внедрение в промышленность, науку, медицину информационных технологий. Вследствие этого процессу обучения информатике уделяется значительное внимание не только в общеобразовательной школе, но и в вузе, в том числе и медицинской направленности. Изучение дисциплины «Медицинская информатика» происходит на втором курсе лечебного и педиатрического факультетов, на первом курсе стоматологического факультета. Количество часов отводимых на изучение дисциплины - 108, три зачётных единицы.

Тема «Обзор методов анализа медицинских изображений» освещает возможности компьютерного моделирования, а так же воссоздания изображения тканей организма, полученных при помощи следующих методов диагностики: MPТ, рентгеновская компьютерная томография, рентгенография, УЗИ, ПЭТ. Научная работа по теме «Использование симуляционных препаратов, созданных посредством томографических $3 \mathrm{~d}$ реконструкций, в изучении нормальной и патологической анатомии» показала возможности использования программы RadiantViewer при использовании медицинских изображений стандарта DICOM для создания учебных материалов как для изучения нормальной, так и патологической анатомии. Разработка научных проектов в области медицинской информатики позволяет расширить кругозор, познавательный интерес студентов в рамках дисциплины, даёт возможность самореализоваться в научноисследовательской деятельности.

В 2015 году в секции «Экологические проблемы Сибири и Дальнего Востока» студентами первого курса лечебного факультета была представлена тема «Оценка влияния шума на показатели активности головного мозга» [2, 
с.60-61]. Работа в данном направлении позволила акцентировать внимание ребят в рамках следующих тем, изучаемых в курсе дисциплины «Физика, математика»: «Электрография», «Теория колебаний. Биоакустика. Звук».

Студентам необходимо было измерить потенциалы головного мозга при наличии благоприятного и неблагоприятного звука, сделать оценку изменения потенциалов. При проведении работы были углублены знания студентов о неблагоприятном воздействии шума на организм человека, о видах звука, об электроэнцефалографии. В данной ситуации студенты не только расширяют знания раздела «Электрография», но и приобретают навык снятия электроэнцефалограммы, её интерпретации.

Таким образом, разработка научного проекта развивает дух коллективизма, способствует сплочённости студентов, в тоже время учит отстаивать собственную точку зрения, брать ответственность на себя, проявлять творческую инициативу при групповой работе, анализировать полученные результаты, способствует саморазвитии и развитию навыков научной работы. Работа по научной тематике способствует систематизации знаний, полученных при изучении дисциплин «Физика, математика» и «Медицинская информатика», углублению знаний дисциплин, полученных как на практических, так и на лекционных занятиях. При проведении научного проекта у студентов формируются умения применять теоретические знания профессиональной направленности на практике.

\section{Литература}

1. Медицина завтрашнего дня: Материалы XV межрегиональной научнопрактической конференции студентов и молодых ученых (Чита, 19-22 апреля 2016 г.). - Чита: РИЦ ЧГМА, 2016. - 370 с.

2. Медицина завтрашнего дня: Материалы XIV научно-практической конференции студентов и молодых ученых / Чита, 22-24 апреля 2015 г. - Ч. II. - Чита: РИЦ ЧГМА, 2015. - 133 с.

3. Федеральный государственный образовательный стандарт высшего образования по направлению подготовки 31.05.01 Лечебное дело (уровень специалитета). М., 2016. 23 с. 